
\title{
25 Research Soure \\ Fungal endophytes of high altitude ethnomedicinal plants as a bioresource of industrially imperative enzymes
}

\section{Neha Kapoor}

Department of Microbiology, Uttaranchal (PG) College of Biomedical Sciences and Hospital, Dehradun, Uttarakhand, India. Department of Biotechnology, School of Applied Sciences, Suresh Gyan Vihar University, Jaipur, Rajasthan, India

\section{Abu Mushtaque}

Department of Microbiology, Uttaranchal (PG) College of Biomedical Sciences and Hospital, Dehradun, Uttarakhand, India

\section{Lokesh Gambhir ( $\square$ gambhir.lokesh@gmail.com )}

Shri Guru Ram Rai University

\section{Research}

Keywords: L-asparaginase, amylase, proteases, cellulases, endophytic fungi

Posted Date: May 29th, 2020

DOI: https://doi.org/10.21203/rs.3.rs-31028/v1

License: (1) (i) This work is licensed under a Creative Commons Attribution 4.0 International License. Read Full License 


\section{Abstract}

Endophytic fungi have been in the spotlight as a reservoir of novel agents with diverse bioactivities. Similarity in chemical diversity with the host plant makes them an amenable target for industrial interventions. A wide range of compounds as secondary metabolites and enzymes are manufactured inside the endophytic fungal factory. However, utilization of endophytic fungi as industrially imperative enzyme producers has been a scarce event. The present study was conducted to bio-prospect the fungal endophytes present in the high altitude medicinal plants of Uttarakhand, as industrially imperative enzyme producers. A total of 58 different endophytic isolates were obtained from Pinus sabiniana, Cinnamomum tamala, Cinnamomum verum, Ocimum tenuiflorum and Rhododendron arboreum. Endophytic fungal colonization was highest, $31 \%$, in Pinus sabiniana. The pure isolates were further explored for the production of amylases, cellulases, proteases and L-asparaginase. Out of 58 isolates, 40 isolates exhibited potent enzyme productivity. \#7PSSTB isolate was considered as superlative contender on account of its relatively higher production of all the three enzymes viz. amylases, cellulases, proteases. Partial purification of \#7PSSTB extract showed compelling enzymatic activity corroborating the existence of exogenous enzyme in the extract. Interestingly, \#9 RASTB, \#11 RASTB and \#17 RASTB exhibited the production of therapeutically imperative L-asparaginase enzyme. The present study puts the spotlight on endophytic diversity in the high altitude medicinal plants as a source of enzymes of industrial interest. Production of L-asparaginase paves the way of pharmaceutical intervention to explore anti-oncogenic effects in the endophytic fungal repository of high altitude regions.

\section{Introduction}

Endophytes are specific group of micro-organisms which colonize plants internally without apparent adverse effects. Endophytic fungi are potent source of novel organic compounds with pharmaceutically important biological activities and a high level of biodiversity (Deshmukh et al. 2018). All nonvascular and vascular plants examined until now have been found to harbor endophytic microbes with the potential to produce novel secondary metabolites. Bio-prospecting of endophytes has unraveled new molecules with therapeutic potentials (Strobel and Daisy 2003). Several endophytic fungi have been reported as potent commercially imperative enzyme producers including Alternaria tangelonis, Cladosporium cladosporioides, Curvularia akaii and Fusarium subglutinans (Masumi et al. 2014), Fusarium solani (Uzma et al. 2016) and Aspergillus terreus (Kalyanasundaram et al. 2015).

Among the repository of fungal enzymes viz. cellulase, amylase, protease and $L$ asparaginase have been investigated for broad spectrum effects. Cellulolytic enzymes have been a focal point of research as a mediator of baggase degradation and second generation ethanol production. cellulase enzymes supplementation can improve the enzymatic hydrolysis of lignocellulosic biomass, in terms of speed and hydrolysis yield. Endophytic fungi viz Botryosphaeria sp. and Saccharicola sp. have been investigated for production of cellulase enzyme (Marques et al. 2018). Amylases are one of the prime industrial enzymes that encompass a wide spectrum of functional applications in pharmaceutical, food, textile and detergent industries. Approx. $30 \%$ of the total enzyme production globally accounts for amylases (de Souza and e 
Magalhães 2010). On the other hand, proteases, an enzyme which breaks proteins to smaller constituents, shares two-third of the world enzyme market. Proteases have profound applications in bioremediation, cosmetics, silk degumming, animal cell culture, therapy, diagnosis, pharmaceutical and food industry (Singh et al. 2016).

L-asparaginase (EC 3.5.11. L-asparaginase amidohydrolase) is widely studied in context to its antitumor potential against tumor of lymphoid precursor, acute lymphoblastic leukemia, acute myeloid leukemia and non-Hodgkin's lymphoma. Regular supply of asparagine, maintained by asparagines synthetase, is requisite for making proteins in the cell. Leukemic cells however are deficient in asparagines synthetase and depend solely on circulating blood for the supply of L-asparagine (Brumano et al. 2019). The immunogenic complications associated with its present microbial sources Escherichia coli, Erwinia caratovora limits its medicinal frontier. Administration of bacterial origin L-asparaginase is associated with allergic reactions and anaphylaxis. Thus, exploring the potential of alternate sources for the production of L-asparaginase has put rich chemical diversity of endophytic fungi under limelight. Lasparaginase derived from endophytic fungi have many benefits over existing preparations like the nonimmunogenic as they are phylogenetically related and posttranslational modifications are present, being the eukaryotic microbes and residing inside the plant body (Sarquis et al. 2004). The present study was undertaken for systematic screening for the production of enzymes and exploration of fungal endophytes from medicinal plants of high altitude regions of Uttarakhand, India.

\section{Methodology}

\section{Plant Sample Collection and isolation of endophytic fungi}

Healthy plant parts (Bark, leaf and stem) of Rhododendron arboreum, Cinnamomum tamala, Cinnamomum verum, Ocimum tenuiflorum and Pinus sabiniana were collected from Bhowali and Nainital located at $29.3823^{\circ} \mathrm{N}, 79.5196^{\circ} \mathrm{E} ; 29.3803^{\circ} \mathrm{N}, 79.4636^{\circ} \mathrm{E}$ in Uttarakhand, India. The stems and leaves were surface sterilized by dipping in $0.1 \%$ sodium hypochlorite for $2-3$ min followed by $70 \%$ ethanol for $1 \mathrm{~min}$ and then subsequent washing by dipping in $30 \%$ ethanol for $30-45 \mathrm{sec}$. Aseptically, the sterilized sample was sectioned into 1-2 mm pieces and were inoculated on to pre sterilized Potato Dextrose Agar (PDA) plates. The plates were then incubated at $26 \pm 2^{\circ} \mathrm{C}, 16 \mathrm{~h} / 8 \mathrm{~h}$ light/Dark condition for 8-10 days. The plates were regularly monitored for any fungal growth. The fungal hyphae emerging out of the segment was transferred to fresh PDA plate aseptically with the help of inoculation loop to obtain pure culture (Hess et al. 2008; Kapoor et al. 2018).

\section{Production Of Secondary Metabolites}

Each fungal endophyte was subjected to culture filtrate production by inoculating $5 \mathrm{~mm}$ mycelial plug of 7 days old active culture into $100 \mathrm{ml}$ pre sterilized PDB medium aseptically and kept on the rotatory shaker at $26 \pm 2^{\circ} \mathrm{C}, 120 \mathrm{rpm}$ for 10 days. After incubation, the culture filtrate rich in bioactive compounds 
were separated from fungal mass by filtration through Whatman filter paper no. 4 followed by centrifugation at 12,000 rpm for 15 min to get cell free culture filtrate (Lobo 2006).

\section{Screening For Extracellular Enzyme Production Protease assay:}

For the protease activity, the skim milk agar plates were prepared containing $1 \%$ skim milk and $1 \%$ agar. $30 \mu \mathrm{l}$ of each culture filtrate was added into $5 \mathrm{~mm}$ wells prepared by sterile cork borer in skim milk agar plates followed by incubation at $37{ }^{\circ} \mathrm{C}$ for $24 \mathrm{~h}$. Un-inoculated PDB served as control. After incubation, a clear zone around the wells indicates the proteolytic activity which was measured in terms of zone diameter and expressed as Mean \pm SD. (Kasana et al. 2011; Pant et al. 2015).

\section{Cellulase assay:}

The modified agar well diffusion method was employed to assess the cellulase activity of fungal isolates as per the method described by (Marques et al. 2018; Legodi et al. 2019). Briefly, Czapek-Dox agar medium plates supplemented with $1 \%$ carboxymethyl cellulose and $1 \%$ Agar was prepared. The plates were allowed to solidify for $30 \mathrm{~min}$ and $5 \mathrm{~mm}$ well were punched out with help of sterile cork borer. The culture filtrate of each fungus was loaded into the wells followed by incubation at $37^{\circ} \mathrm{C}$ for $18-24 \mathrm{~h}$. After the incubation, the plates were flooded with aqueous Congo red solution. The appearance of yellow zone around the fungal colony indicated cellulolytic activity. The zone diameter was measured and represented as Mean \pm SD.

\section{Amylase activity assay}

Amylase activity was assessed by preparing the $1 \%$ starch agar plate by following the procedure of (Hankin and Anagnostakis 1975). The plates were solidified for $30 \mathrm{~min}$ and $5 \mathrm{~mm}$ well were punched out with help of sterile cork borer. The culture filtrate of each fungus was loaded into the wells followed by incubation at $37^{\circ} \mathrm{C}$ for $18-24 \mathrm{~h}$. Un-inoculated media served as control. After the incubation, the plates were flooded with the $1 \%$ lodine solution. Appearance of clear zone around the fungal colony indicated amylolytic activity which was measured in terms of zone diameter and represented as Mean \pm SD.

\section{Asparaginase Activity assay}

Asparaginase production by the fungal endophytes was assessed by modified Ditch plate assay (Mahajan et al. 2013). Briefly describing, L- asparaginase-agar ( $2 \%$ ) plates were prepared by adding $2 \% \mathrm{~L}-$ asparagine supplemented with $0.009 \%$ phenol red. Each plate was divided into four quadrants followed by preparation of $5 \mathrm{~mm}$ wells in each quadrant using pre-sterilized cork borer. Further, $30 \mu \mathrm{l}$ of culture filtrates of each fungal endophyte were dispensed into the wells followed by incubation at $37^{\circ} \mathrm{C}$ for $24 \mathrm{~h}$. After the incubation period, the plates were observed for the pink halo formation around the wells. The zone diameter was recorded and expressed as Mean \pm SD. 


\section{Mass Production And Partial Purification By "Salting Out"}

For the partial purification of desired enzyme, the potential endophytic fungi was subjected to mass fermentation of $1 \mathrm{~L}$ by inoculating $5 \mathrm{~mm}$ active mycelial plug of selected fungal endophyte in 10 Erlenmeyer flask containing $100 \mathrm{ml}$ pre-sterilized PDB medium followed by incubation at $28^{\circ} \mathrm{C}, 120 \mathrm{rpm}$ for 7-10 days. After the incubation period, cell mass and culture filtrate was separated by filtration through Whatman filter paper No. 4 followed by centrifugation at $10,000 \mathrm{rpm}$ for $10 \mathrm{~min}$ at $4^{0} \mathrm{C}$ in refrigerated centrifuge. The obtained supernatant was then further subjected for precipitation of enzymatic protein by employing ammonium sulphate salting out method. Briefly, ammonium sulphate was slowly added to the culture broth to achieve saturation with slow and continuous stirring at $4{ }^{\circ} \mathrm{C}$. The mixture was then incubated overnight at $4^{\circ} \mathrm{C}$ and the next day protein precipitate was collected by centrifugation at $12,000 \mathrm{rpm}$ for $15 \mathrm{~min}$ at $4{ }^{\circ} \mathrm{C}$. The obtained precipitate was dissolved in minimum

volume of $20 \mathrm{mM}$ Tris- $\mathrm{HCl}$ buffer (pH 7.8) and analyzed for enzymatic activities (Raul et al. 2014; Pant et al. 2015).

\section{Statistical Analysis}

The statistical analysis was done using analysis of variance with GraphPad Prism 5 software followed by Tukey's post-hoc test $(p<0.05)$. Data points were obtained from three replicates, and two independent experiments were performed.

\section{Results}

\section{Fungal endophytes were isolated from medicinal plants}

A total of 58 different fungal endophytes were isolated from various medicinal parts (Table 1, Fig. 1). Maximum fungal endophytes were recovered from Pinus sp. (31.0\%) followed by $C$. tamala (27.5\%) and $R$. arboreum (25.8\%). However least fungal colonization was observed in $C$. verum (5.1\%). The host tissue of each plant sample exhibited a variation in colonization of the endophytic mycoflora. Further, colonization in different parts of plants was estimated. It was observed that maximum fungal colonization was observed in stem (62.1\%) followed by leaf (24.1\%). However, bark and stem internal tissues were least colonized by endophytes (Fig. 2). 
Table 1

Details of fungal endophytes along with assigned culture code, plant name, plant part and sample collection site recovered from different medicinal plants under study

\begin{tabular}{|c|c|c|c|c|}
\hline S.NO. & CULTURE CODE & PLANT NAME & PART & PLACE \\
\hline 1. & \# 7 RALFB & R. arboberum & Leaf & Bhowali \\
\hline 2. & \# 18 RALFB & R. arboberum & Leaf & Bhowali \\
\hline 3. & \# 21 RALFB & R. arboberum & Leaf & Bhowali \\
\hline 4. & \# 25 RALFB & R. arboberum & Leaf & Bhowali \\
\hline 5. & \# 1 RASTB & R. arboberum & Stem & Bhowali \\
\hline 6. & \# 4 RASTB & R. arboberum & Stem & Bhowali \\
\hline 7. & \# 5 RASTB & R. arboberum & Stem & Bhowali \\
\hline 8. & \# 11 RASTB & R. arboberum & Stem & Bhowali \\
\hline 9. & \# 15 RASTB & R. arboberum & Stem & Bhowali \\
\hline 10. & \# 17 RASTB & R. arboberum & Stem & Bhowali \\
\hline 11. & \# 26 RASTB & R. arboberum & Stem & Bhowali \\
\hline 12. & \# 27 RASTB & R. arboberum & Stem & Bhowali \\
\hline 13. & \# 28 RASTB & R. arboberum & Stem & Bhowali \\
\hline 14. & \# 29 RASTB & R. arboberum & Stem & Bhowali \\
\hline 15. & \# 9 RASTITB & R. arboberum & Stem internal tissue & Bhowali \\
\hline 16. & \# 2a PSSTB & Pinus sabiniana & Stem & Bhowali \\
\hline 17. & \# 2b PSSTB & Pinus sabiniana & Stem & Bhowali \\
\hline 18. & \# 4 PSSTB & Pinus sabiniana & Stem & Bhowali \\
\hline 19. & \# 5 PSSTB & Pinus sabiniana & Stem & Bhowali \\
\hline 20. & \# 7 PSSTB & Pinus sabiniana & Stem & Bhowali \\
\hline 21. & \# 9 PSSTB & Pinus sabiniana & Stem & Bhowali \\
\hline 22. & \# 13c PSSTB & Pinus sabiniana & Stem & Bhowali \\
\hline 23. & \# 14b PSSTB & Pinus sabiniana & Stem & Bhowali \\
\hline
\end{tabular}

Each endophytic fungal isolate was encoded based on the host plant, its part (LF for Leaf, ST for stem, STIT for stem internal tissue and B for Bark) and the place from where it was collected. For instance in \#7 RALFB, \#7 refers to the segment number, RA refers to the host medicinal plant scientific name, LF refers to leaf as explants for isolation and B refers to Bhowali the place of collection 


\begin{tabular}{|c|c|c|c|c|}
\hline S.NO. & CULTURE CODE & PLANT NAME & PART & PLACE \\
\hline 24. & \# 14c PSSTB & Pinus sabiniana & Stem & Bhowali \\
\hline 25. & \# 15a PSSTB & Pinus sabiniana & Stem & Bhowali \\
\hline 26. & \# 15b PSSTB & Pinus sabiniana & Stem & Bhowali \\
\hline 27. & \# 15c PSSTB & Pinus sabiniana & Stem & Bhowali \\
\hline 28. & \# 16 PSSTB & Pinus sabiniana & Stem & Bhowali \\
\hline 29. & \# 16а PSSTB & Pinus sabiniana & Stem & Bhowali \\
\hline 30. & \# 17c PSSTB & Pinus sabiniana & Stem & Bhowali \\
\hline 31. & \# 08 PSSTITB & Pinus sabiniana & Stem internal tissue & Bhowali \\
\hline 32. & \# 10 PSSTITB & Pinus sabiniana & Stem internal tissue & Bhowali \\
\hline 33. & \# 18a PSSTITB & Pinus sabiniana & Stem internal tissue & Bhowali \\
\hline 34. & \# 1 OTLFN & O. tenuiflorum & Leaf & Nainital \\
\hline 35. & \# 14 OTLFN & O. tenuiflorum & Leaf & Nainital \\
\hline 36. & \# 16 OTLFN & O. tenuiflorum & Leaf & Nainital \\
\hline 37. & \# 18 OTLFN & O. tenuiflorum & Leaf & Nainital \\
\hline 38. & \# 10 OTSTN & O. tenuiflorum & Stem & Nainital \\
\hline 39. & \# 15 OTSTN & O. tenuiflorum & Stem & Nainital \\
\hline 40. & \# 1 CTLFN & C. tamala & Leaf & Nainital \\
\hline 41. & \# 15 CTLFN & C. tamala & Leaf & Nainital \\
\hline 42. & \# 18 CTLFN & C. tamala & Leaf & Nainital \\
\hline 43. & \# 21 CTLFN & C. tamala & Leaf & Nainital \\
\hline 44. & \# 27 CTLFN & C. tamala & Leaf & Nainital \\
\hline 45. & \# 32 CTLFN & C. tamala & Leaf & Nainital \\
\hline 46. & \# 2 CTSTN & C. tamala & Stem & Nainital \\
\hline 47. & \# 4 CTSTN & C. tamala & Stem & Nainital \\
\hline 48. & \# 5 CTSTN & C. tamala & Stem & Nainital \\
\hline
\end{tabular}

Each endophytic fungal isolate was encoded based on the host plant, its part (LF for Leaf, ST for stem, STIT for stem internal tissue and B for Bark) and the place from where it was collected. For instance in \#7 RALFB, \#7 refers to the segment number, RA refers to the host medicinal plant scientific name, LF refers to leaf as explants for isolation and B refers to Bhowali the place of collection 


\begin{tabular}{|c|c|c|c|c|}
\hline S.NO. & CULTURE CODE & PLANT NAME & PART & PLACE \\
\hline 49. & \# 6 CTSTN & C. tamala & Stem & Nainital \\
\hline 50. & \# 8 CTSTN & C. tamala & Stem & Nainital \\
\hline 51. & \# 10 CTSTN & C. tamala & Stem & Nainital \\
\hline 52. & \# 11 CTSTN & C. tamala & Stem & Nainital \\
\hline 53. & \# 13 CTSTN & C. tamala & Stem & Nainital \\
\hline 54. & \# 14 CTSTN & C. tamala & stem & Nainital \\
\hline 55. & \# 11 CTSTITN & C. tamala & Stem internal tissue & Nainital \\
\hline 56. & \# 5 CVBN & C. verum & Bark & Nainital \\
\hline 57. & \# 6a CVBN & C. verum & Bark & Nainital \\
\hline 58. & \# 18 CVBN & C. verum & Bark & Nainital \\
\hline \multicolumn{5}{|c|}{$\begin{array}{l}\text { Each endophytic fungal isolate was encoded based on the host plant, its part (LF for Leaf, ST for } \\
\text { stem, STIT for stem internal tissue and B for Bark) and the place from where it was collected. For } \\
\text { instance in \#7 RALFB, \#7 refers to the segment number, RA refers to the host medicinal plant } \\
\text { scientific name, LF refers to leaf as explants for isolation and B refers to Bhowali the place of } \\
\text { collection }\end{array}$} \\
\hline
\end{tabular}

\section{Screening Of Protease Producing Endophytic Fungal Isolates}

In the preliminary screening studies, 31 endophytes out of 58 exhibited proteolytic activity (Table 2;

Fig. 3). As per One-way ANOVA analysis $[\mathrm{F}(38,76)=231.4,<0.001]$ and Tukey's post hoc analysis, \#7PSSTB exhibited relatively highest protease production with zone size of $24 \mathrm{~mm}$ followed by \#13CTSTN and \#6CVSTN with the zone size of $21.6 \mathrm{~mm}$ and $20.6 \mathrm{~mm}$ respectively. Further, moderate level of activity was observed in \#15bPSSTB and \#180TLFN and least activity was recorded in \#1RASTB, \#4PSSTB, \#8PSTITB and \#5CTSTN. 
Table 2

in vitro enzyme production of 40 fungal endophytes (out of total 58 endophytes, 18 endophytes did not exhibited any activity)

\section{S.NO. CULTURE CODE Average Zone size (in mm)}

PROTEASE

1. - \# 21 RALFB

2. \# 25 RALFB

3. \# 1 RASTB

4. \# 4 RASTB

5. \# 5 RASTB

6. \# 9 RASTB

7. \# 11 RASTB

8.

9. \# 26 RASTB

10. \# 27 RASTB

11. \# 28 RASTB

12. \# 29 RASTB

13. \# 2b PSSTB

14. \# 4 PSSTB

15. \# 7 PSSTB

16. \# 9 PSSTB

17. \# 14b PSSTB

18. \# 14c PSSTB

19. \# 15a PSSTB

20. \# 15b PSSTB

21. \# 15c PSSTB

$9.0 \pm 0.0^{\mathrm{ijk}}$

-
AMYLASE

-
-
13
-

$12.3 \pm 0.58 \mathrm{ab}$

$-$

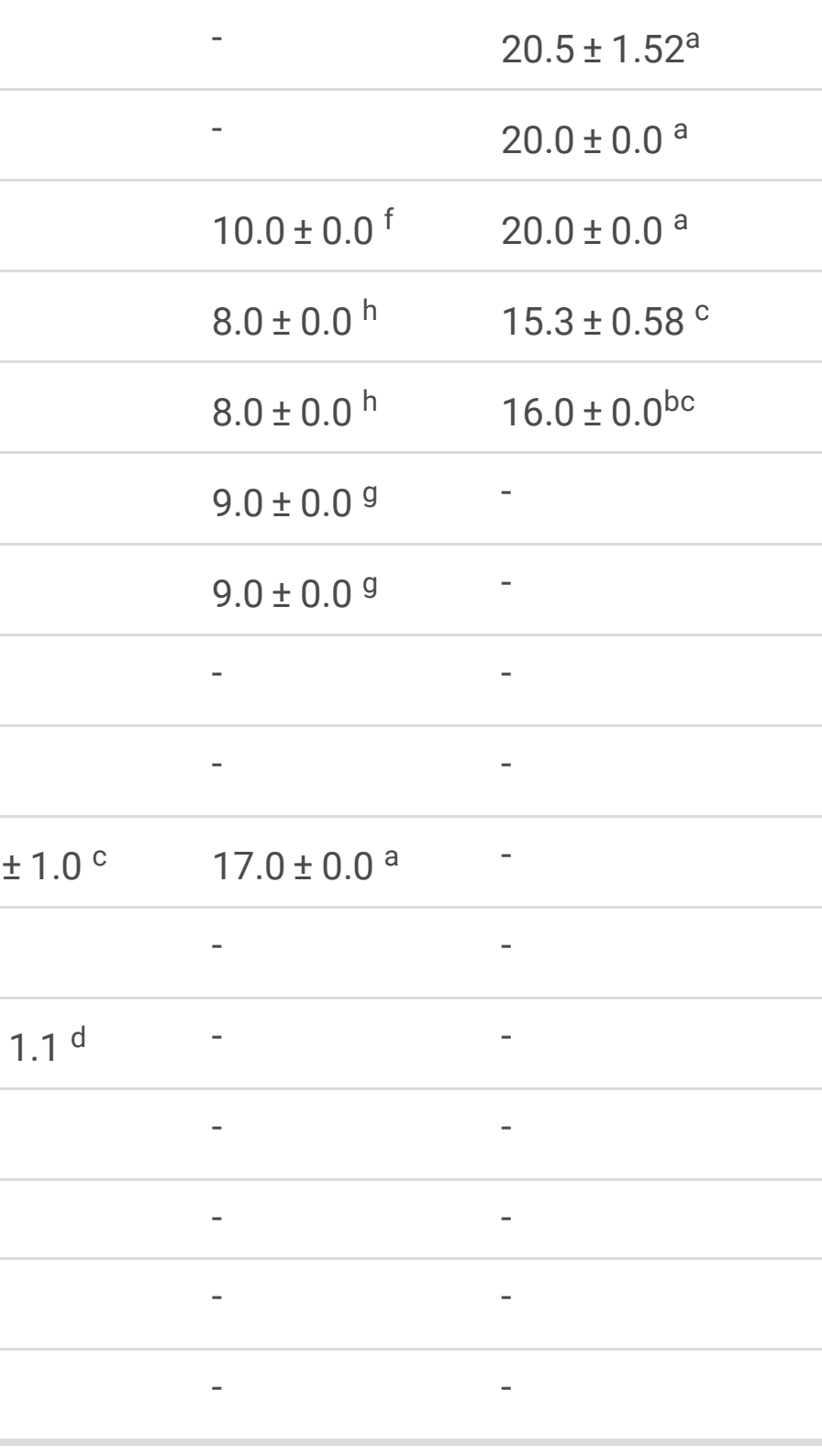

${ }^{*}$ Data presented as mean \pm standard deviation of three replicates. Means with different superscript letters are different by Tukey's post-hoc test $(p<0.05)$. 


\begin{tabular}{|c|c|c|c|c|c|}
\hline \multirow[t]{2}{*}{ S.NO. } & \multirow[t]{2}{*}{ CULTURE CODE } & \multicolumn{4}{|c|}{ Average Zone size (in mm) } \\
\hline & & PROTEASE & AMYLASE & CELLULASE & L-ASPARAGINASE \\
\hline 22. & \# 16 PSSTB & - & $12.0 \pm 0.0^{b}$ & $11.6 \pm 0.58 \mathrm{de}$ & - \\
\hline 23. & \# 16а PSSTB & - & - & $15.6 \pm 0.58 b$ & - \\
\hline 24. & \# 8 PSSTITB & $7.0 \pm 0.0 \mathrm{jk}$ & - & - & - \\
\hline 25. & \# 10 PSSTITB & $8.0 \pm 0.0 \mathrm{jk}$ & - & $9.0 \pm 0.0 \mathrm{~g}$ & - \\
\hline 26. & \# 18a PSSTITB & $15.0 \pm 2.0$ def & - & - & - \\
\hline 27. & \# 14 OTLFN & $12.0 \pm 0.0 \mathrm{gh}$ & - & - & - \\
\hline 28. & \# 18 OTLFN & $18.0 \pm 1.0^{c}$ & - & - & - \\
\hline 29. & \# 10 OTSTN & - & - & - & - \\
\hline 30. & \# 15 OTSTN & $7.3 \pm 0.58^{\mathrm{jk}}$ & - & - & - \\
\hline 31. & \# 1 CTLFN & $15.0 \pm 1.0$ def & - & - & $8.0 \pm 0.0^{d}$ \\
\hline 32. & \# 32 CTLFN & $16.0 \pm 1.0^{\mathrm{cd}}$ & - & - & - \\
\hline 33. & \# 5 CTSTN & $7.0 \pm 0.0^{j \mathrm{jk}}$ & - & - & - \\
\hline 34. & \# 6 CTSTN & $20.6 \pm 0.58^{b}$ & - & $14.6 \pm 0.58^{c}$ & - \\
\hline 35. & \# 8 CTSTN & $14.0 \pm 0.0$ defg & - & - & - \\
\hline 36. & \# 10 CTSTN & - & - & $10.0 \pm 0.0^{f}$ & - \\
\hline 37. & \# 13 CTSTN & $21.6 \pm 0.58^{a b}$ & - & $14.6 \pm 0.58^{c}$ & - \\
\hline 38. & \# 14 CTSTN & $15.6 \pm 0.58^{\text {cde }}$ & - & - & - \\
\hline 39. & \# 5 CVBN & $12.3 \pm 2.08^{g h}$ & - & - & - \\
\hline 40. & \# 6а CVBN & $12.0 \pm 0.0 \mathrm{gh}$ & - & $11.0 \pm 1.0^{\mathrm{e}}$ & \\
\hline
\end{tabular}

\section{Screening Of Amylase Producing Endophytic Fungal Isolates}


In the amylolytic screening assay, only 5 endophytes exhibited the amylase producing potential. As per One-way ANOVA analysis [F $(38,76)=469.2,<0.001]$ and Tukey's post hoc analysis, \#1 RASTB was found to be potent amylase producer with zone size of $13.0 \mathrm{~mm}$ followed by \#5 RASTB with zone size of 12.3 mm (Fig. 4a-b). However, least activity was observed in \#14b PSSTB.

\section{Screening Of Cellulase Producing Fungal Endophytic Isolates}

Cellulose is imperative in leather, detergents and food processing industries. In the cellulolytic activity, 15 endophytes out of 58 showed positive results. As per One-way ANOVA analysis [F $(38,76)=1473,<0.001]$ and Tukey's post hoc analysis, maximum activity was recorded in \#7 PSSTB with a zone size of $17.0 \mathrm{~mm}$ followed by \#16a PSSTB with zone size of $16.3 \mathrm{~mm}$. However least activity was recorded in \#26RASTB and \#27RASTB with zone size of $8.0 \mathrm{~mm}$ (Fig. 4c-f).

\section{Screening Of L-asparaginase Producing Fungal Endophytes}

The isolated endophytic fungal isolates were screened for the production of L-asparaginase enzyme. In the L-asparaginase screening assay, 9 endophytes were found to be potent L-asparaginase producer. One-way ANOVA analysis $[F(9,18)=130.3,<0.001]$ and Tukey's post hoc analysis revealed maximum Lasparaginase production in \#9 RASTB with a zone size of $20.3 \mathrm{~mm}$ followed by \#11 RASTB and \#17 RASTB with zone size of $20 \mathrm{~mm}$ (Table 2; Fig. 5).

\section{Bioactivity Screening Of Partially Purified Protein}

Further the protein purification was done from the endophytic fungal isolates using salting out method and evaluated for enzyme activities. The partially purified protein of \#7PSSTB, opted due to consistent best results in all the three screenings, was again subjected for bioactivity profiling. In protease, amylase and cellulase activity assay, zone size of $16 \mathrm{~mm}, 12 \mathrm{~mm}$ and $16 \mathrm{~mm}$ respectively was obtained (Fig. 6).

\section{Discussion}

Endophytic fungi have been investigated as repository of bioactive metabolites for industrial and therapeutic applications. Being in symbiotic association with the host plant endophytic fungi shares the similar chemical diversity as that of the plant (Jia et al. 2016; Khare et al. 2018). Therefore, the endophytic fungi, ubiquitous in medicinal plants, have been investigated for the production of novel metabolites with cost effective industrial applications. Studies have revealed that around 1 million species of endophytic fungi are residing in plants. A study of endophytic fungi from tropical and temperate forests supports the high estimates of species diversity (Strobel and Daisy 2003). Over two decades endophytic fungi have been investigated for the novel chemistries targeting a spectrum of 
bioactivities. They have been recognized as primary resource for harnessing antibiotics, anticancer, immunomodulatory, antiparasitic etc. compounds. Apart from these therapeutic compounds, endophytic fungi have long been known as potent hydrolytic and oxidative enzyme producers (Sahoo et al. 2018). Production of enzymes such as amylases, cellulase and proteases by endophytic fungi is done to combat the host plant defence and to attain the desired nutrients for their sustenance. However, less attention has been given to the use of endophytic fungi as potent industrial enzyme producers.

The present study was done to investigate the potential of endophytic fungi isolated from high altitude medicinal plants of Uttarakhand as commercially imperative enzyme producers. Medicinal plants viz Rhododendron arboreum, Cinnamomum tamala, Cinnamomum verum, Ocimum tenuiflorum and Pinus sabiniana were selected for bioprospecting of endophytic fungi. The explants were subjected to endophytic isolation and 58 different fungal endophytes were isolated (Table 1). Maximum colonization of endophytic fungi was observed in Pinus sabiniana and stem as an explant source (Fig. 2). Further, the isolates were screened for production of industrially and medicinally useful enzymes such as amylases, cellulases, proteases and L-asparaginase. Out of the 58 isolated endophytic fungi 40 isolates were found to be enzyme producers with varying degree of productivity whereas 18 isolates did no showed any enzymatic activity. \#7PSSTB isolate was selected as the best candidate for further screening owing to its potential of relatively higher production of all the three enzymes viz. amylases, cellulases, proteases (Table 2). Further, crude protein mixture obtained after partial purification of extracts exhibited potent enzymatic activity contemplating the presence of exogenous enzyme in the isolated endophytic fungi. Lasparaginase has been shown to exhibit a profound tumor suppressive activity (Mohamed Shebany et al. 2016). Interestingly, L-asparaginase production was also observed in the endophytic isolates mainly \#9 RASTB, \#11 RASTB and \#17 RASTB. Production of L-asparaginase further substantiated the imperative reserve of endophytic fungi as pharmaceutically important repository.

\section{Conclusion}

Medicinal plants of high altitude Himalayan regions of Uttarakhand have been used for potent medicinal properties. Endophytic fungi present in medicinal plants provide an alternate itinerary to exploit the bioactive chemistries analogous to host plant. Very few reports have demonstrated the bioprospecting endophytic fungi from high altitude medicinal plants. The present study demonstrates the colonization of endophytic fungi in Rhododendron arboreum, Cinnamomum tamala, Cinnamomum verum, Ocimum tenuiflorum and Pinus sabiniana. The present study paves the way for exploration of endophytic fungi as industrially viable enzyme producers. More studies are warranted to optimize the enzyme production from isolated fungal endophytes and characterization of its physiochemical properties.

\section{Abbreviations}

PDA

Potato Dextrose Agar

Rpm 
Rotation per minute

SD

Standard Deviation

ANOVA

Analysis of Variance

LF

Leaf

ST

stem

STIT

stem internal tissue

B

Bark

RA

Rhododendron arboreum

CT

Cinnamomum tamala

CV

Cinnamomum verum

OT

Ocimum tenuiflorum

PS

Pinus sabiniana

\section{Declarations}

\section{Ethics approval and consent to participate}

Not applicable

Consent for publication

All the authors have read and are in consent to submit it to Bioresources and Bioprocessing.

Availability of data and materials

The data pertaining to this article are incorporated in the manuscript.

\section{Competing interest}

There is no actual or potential competing interest. 


\section{Funding}

Not applicable

\section{Acknowledgement}

Authors would like to acknowledge the Managing Director, Uttaranchal (PG) College of Biomedical Sciences and Hospital for providing necessary infrastructural facilities to carry out the work.

\section{Author's contributions}

NK and AM performed the experiments. NK and LG conceived the idea and designed the research. LG and NK analyzed the data and all the authors contributed in writing the manuscript.

\section{References}

1. Brumano LP, da Silva FVS, Costa-Silva TA et al (2019) Development of L-asparaginase biobetters: Current research status and review of the desirable quality profiles. Front. Bioeng. Biotechnol. 6

2. de Souza PM, e Magalhães P de $O$ (2010) Application of microbial a-amylase in industry - a review. Brazilian J Microbiol 41:850-861

3. Deshmukh SK, Gupta MK, Prakash V, Saxena S (2018) Endophytic fungi: A source of potential antifungal compounds. J. Fungi 4

4. Hankin L, Anagnostakis SL (1975) The Use of Solid Media for Detection of Enzyme Production by Fungi. Mycologia 67:597-607. https://doi.org/10.1080/00275514.1975.12019782

5. Hess AM, Vargas WM, Ezra PN (2008) Muscodor crispans, a novel endophyte from Ananas ananassoides in the Bolivian Amazon

6. Jia M, Chen L, Xin HL et al (2016) A friendly relationship between endophytic fungi and medicinal plants: A systematic review. Front. Microbiol. 7

7. Kalyanasundaram I, Nagamuthu J, Srinivasan B et al (2015) Production, purification and characterisation of extracellular l-asparaginase from salt marsh

8. Kapoor N, Rajput P, Mushtaque A, Gambhir L (2018) Bio-prospecting fungal endophytes of high altitude medicinal plants for commercially imperative enzymes. Biotechnol Commun Biosci Biotech Res Comm 11:370-375. https://doi.org/10.21786/bbrc/11.3/4

9. Kasana RC, Salwan R, Yadav SK (2011) Microbial proteases: Detection, production, and genetic improvement. Crit Rev Microbiol 37:262-276

10. Khare E, Mishra J, Arora NK (2018) Multifaceted interactions between endophytes and plant: Developments and Prospects. Front. Microbiol. 9 
11. Legodi LM, Grange D, La J, Van Rensburg EL, Ncube I (2019) Isolation of Cellulose Degrading Fungi from Decaying Banana Pseudostem and Strelitzia alba. https://doi.org/10.1155/2019/1390890

12. Lobo M (2006) Antimicrobial Evaluation of Endophytic Fungi Inhabiting Medicinal Plants of the Western Ghats of India Decomposition View project Biodiversity View project Raviraja N Seetharam Stempeutics Research Antimicrobial Evaluation of Endophytic Fungi Inhabiting Medicinal Plants of the Western Ghats of India. https://doi.org/10.1002/elsc.200620145

13. Mahajan R V., Saran S, Saxena RK, Srivastava AK (2013) A rapid, efficient and sensitive plate assay for detection and screening of $<\mathrm{scp}>1</ \mathrm{scp}>$-asparaginase-producing microorganisms. FEMS Microbiol Lett 341:122-126. https://doi.org/10.1111/1574-6968.12100

14. Marques NP, de Cassia Pereira J, Gomes E et al (2018) Cellulases and xylanases production by endophytic fungi by solid state fermentation using lignocellulosic substrates and enzymatic saccharification of pretreated sugarcane bagasse. Ind Crops Prod 122:66-75.

https://doi.org/10.1016/j.indcrop.2018.05.022

15. Masumi S, Mirzaei S, Kalvandi R, Zafari D (2014) Asparaginase and amylase activity of thyme endophytic fungi

16. Mohamed Shebany Y, Hussein M, Dawy E El (2016) Antimicrobial and L-asparaginase activities of endophytic fungi isolated from Datura innoxia and Hyoscyamus muticus medicinal plants. Eur J Biol Res Res Artic Eur J Biol Res 6:135-144. https://doi.org/10.5281/zenodo.56056

17. Pant G, Prakash A, Pavani JVP et al (2015) Production, optimization and partial purification of protease from Bacillus subtilis. J Taibah Univ Sci 9:50-55.

https://doi.org/10.1016/j.jtusci.2014.04.010

18. Raul D, Biswas T, Mukhopadhyay S et al (2014) Production and Partial Purification of Alpha Amylase from Bacillus subtilis (MTCC 121) Using Solid State Fermentation.

https://doi.org/10.1155/2014/568141

19. Sahoo S, Sarangi S, Kerry RG (2018) Bioprospecting of endophytes for agricultural and environmental sustainability. In: Microbial Biotechnology. Springer Singapore, pp 429-458

20. Sarquis MI, de M, Oliveira, Santos EMM, AS, Costa GL da (2004) Production of L-asparaginase by filamentous fungi. Mem Inst Oswaldo Cruz 99:489-492. https://doi.org/10.1590/s007402762004000500005

21. Singh R, Kumar M, Mittal A, Mehta PK (2016) Microbial enzymes: industrial progress in 21st century. 3 Biotech 6

22. Strobel G, Daisy B (2003) Bioprospecting for Microbial Endophytes and Their Natural Products. Microbiol Mol Biol Rev 67:491-502. https://doi.org/10.1128/mmbr.67.4.491-502.2003

23. Uzma F, Murthy N, Srinivas C (2016) Optimization of physiological conditions for L-asparaginase production by endophytic fungi (Fusarium solani) isolated from Tinospora cordifolia (Willd.) Hook. $F$ \& Thomson

\section{Figures}



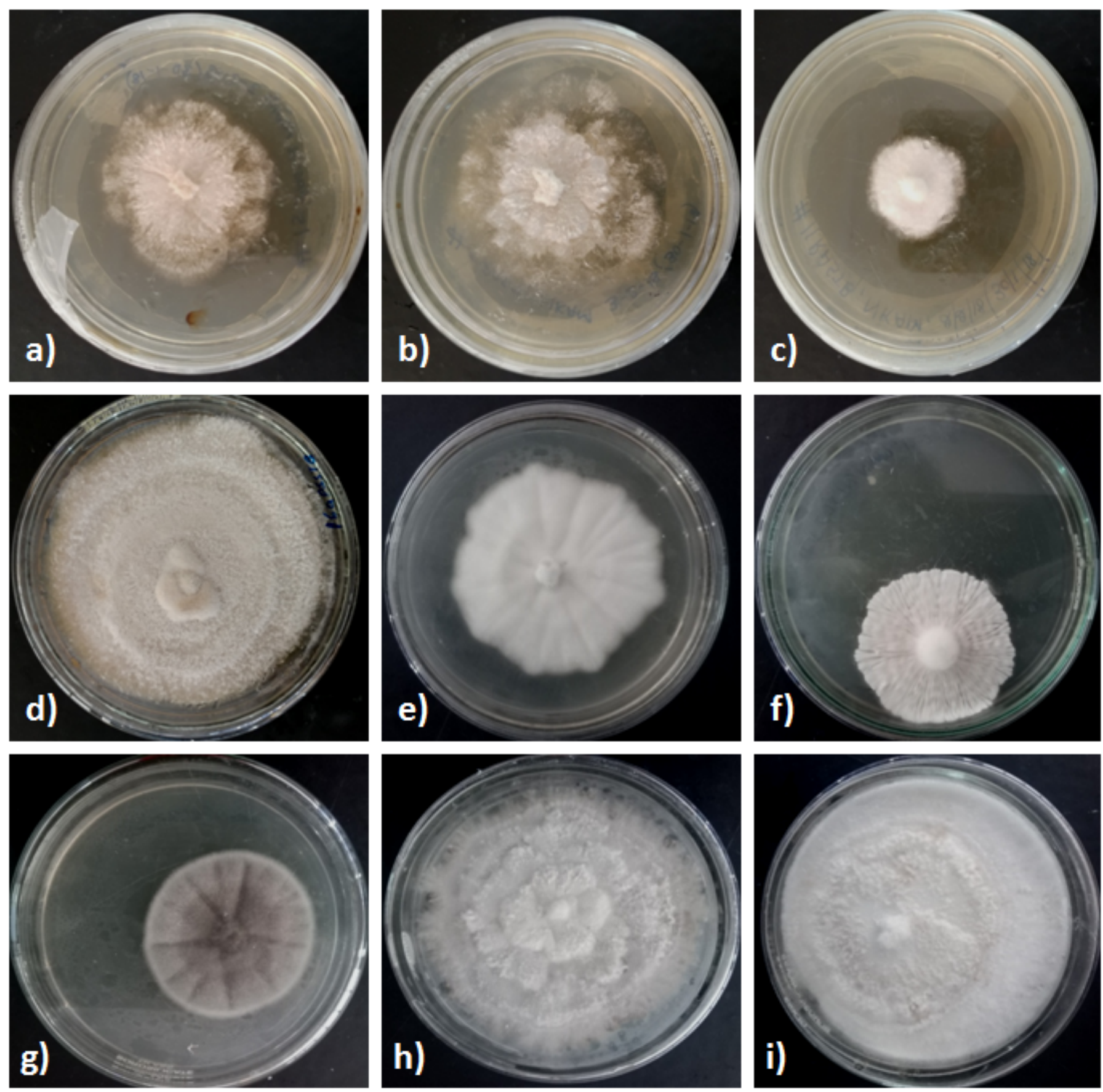

Figure 1

Fungal endophytes obtained from high altitude ethnomedicinal plants of Uttarakhand viz. Pinus sabiniana, Cinnamomum tamala, Cinnamomum verum, Ocimum tenuiflorum and Rhododendron arboreum used in the study: (a) \#12 RASTB, (b) \#5 RASTITB, (c) \#11 RASTB, (d) \# 16a PSSTB, (e) \#15a PSSTB, (f) \#5 CTSTN, (g) \#9 CTSTN, (h) \#18 RALB, (i) \#12 RALB. 

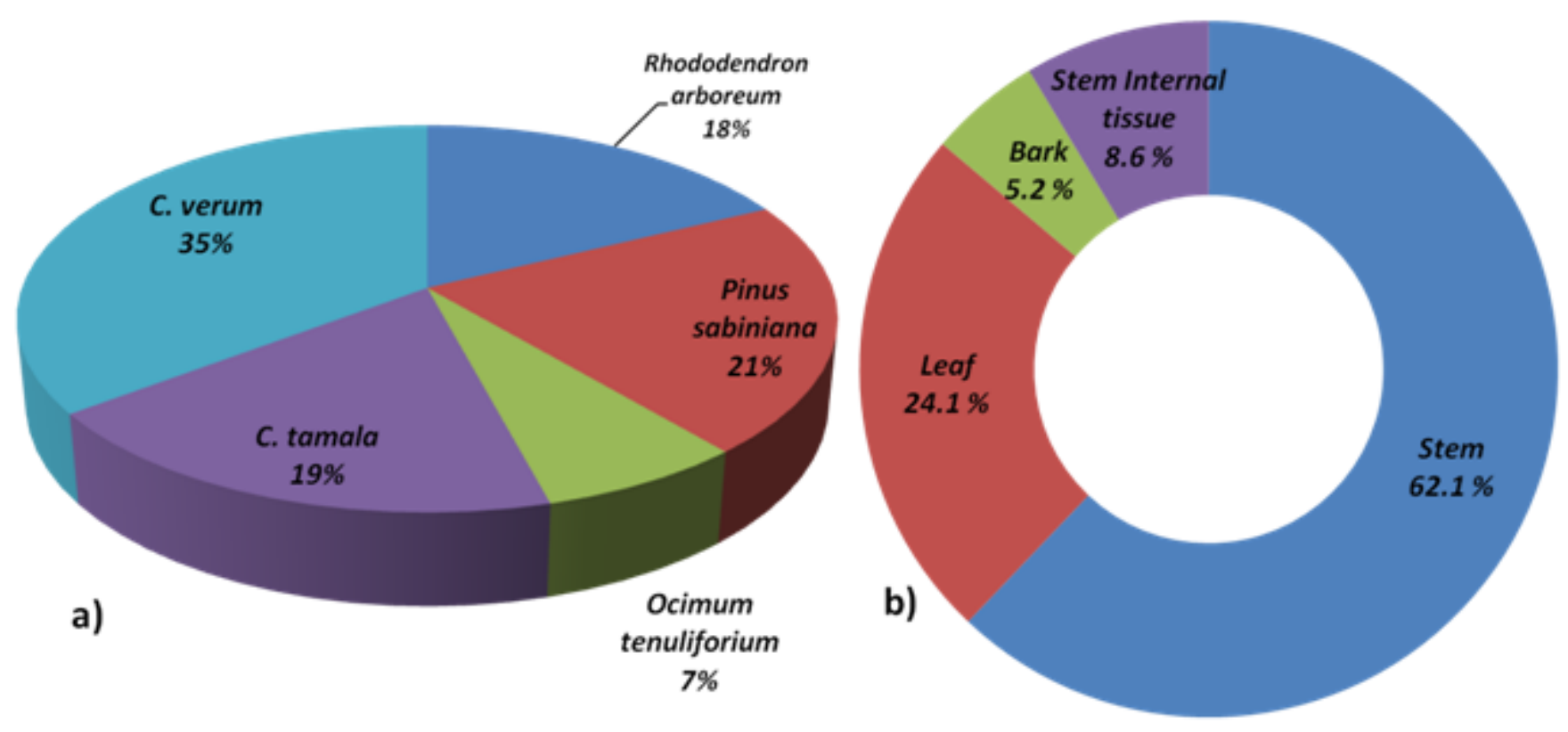

Figure 2

Colonization frequency of fungal endophytes was graphed as percentage distributions of fungal endophytes in (a) host plant, maximum colonization of $31 \%$ was observed in Pinus sabiniana. (b) host tissue, maximum colonization was observed in stem compared with leaf, stem internal tissue and bark.
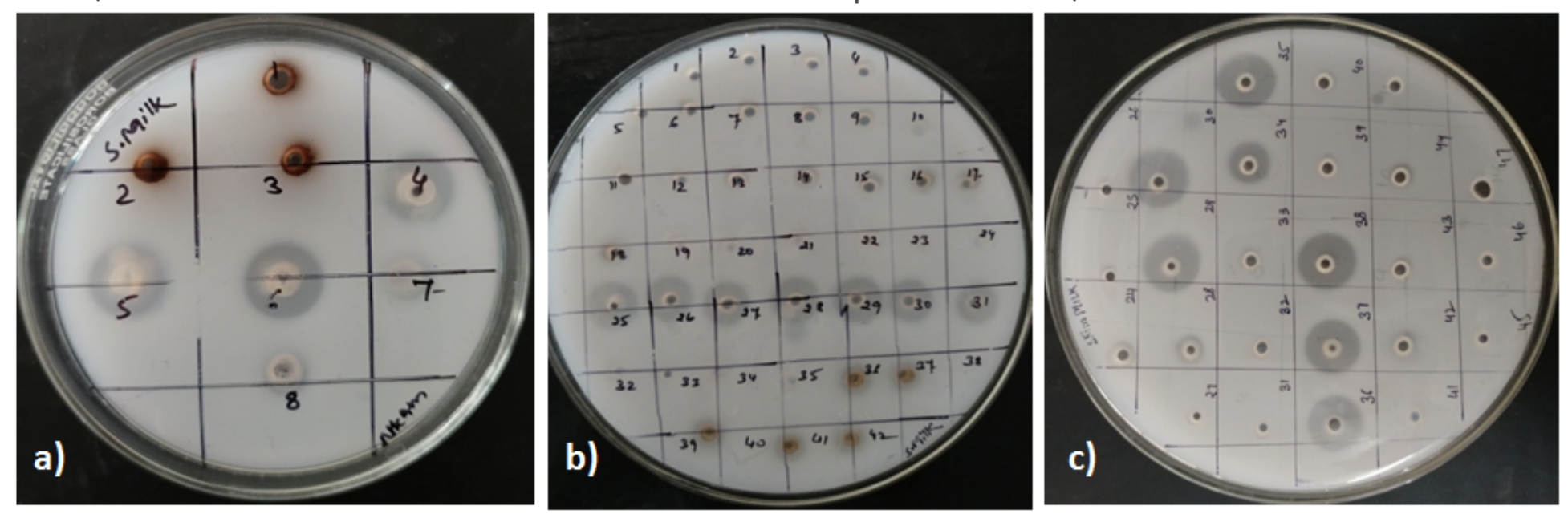

\section{Figure 3}

(a-c) Proteolytic activity of culture filtrates obtained from 10 days old endophytic fungal batch fermentation. Zone of clearance against white background is observed among positive isolates over skim milk agar plate. 

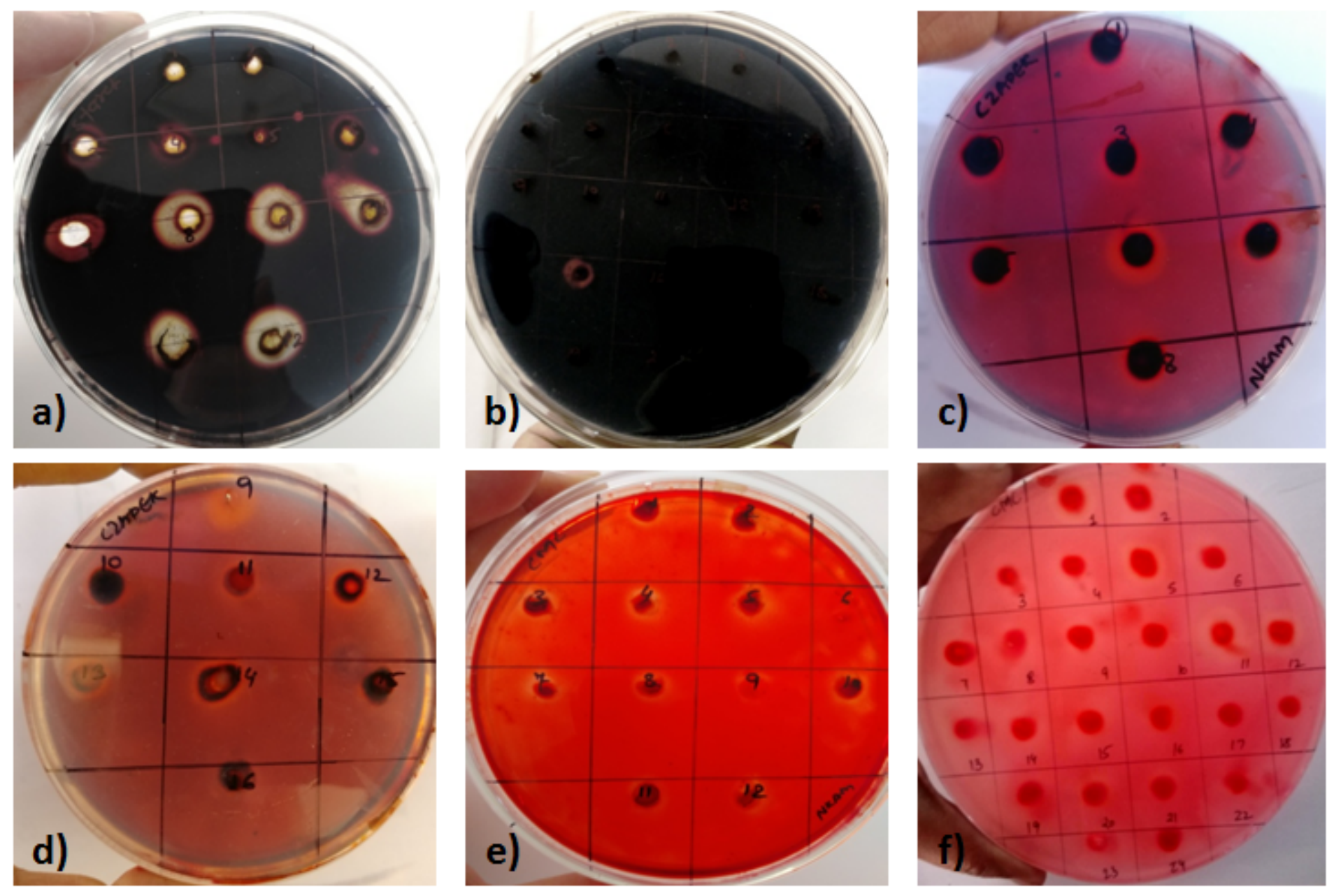

\section{Figure 4}

Amylase and cellulase production exhibited by culture filtrates of different fungal endophytes. (a-b) amylolytic activity as indicated by clear zone around the well over starch agar plate stained by lodine solution (c-f) cellulolytic activity as indicated by pale yellow halo around well over carboxymethyl cellulose agar plate stained with congo red dye.
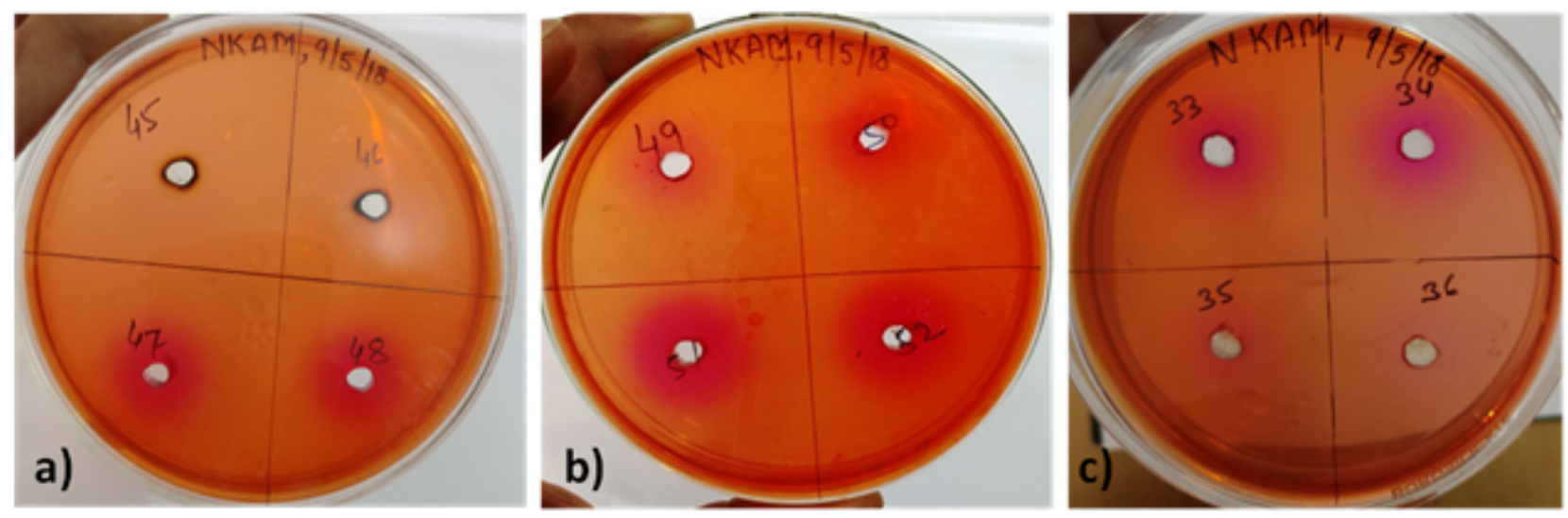

\section{Figure 5}

(a-c) L-asparaginase enzyme production by culture filtrates obtained from 10 days old of different fungal endophytes as indicated by dark pink color halo around the well over Asparagine-phenol red agar plate. 
Maximum L-asparaginase production was observed in \#9 RASTB with a zone size of $20.3 \mathrm{~mm}$.
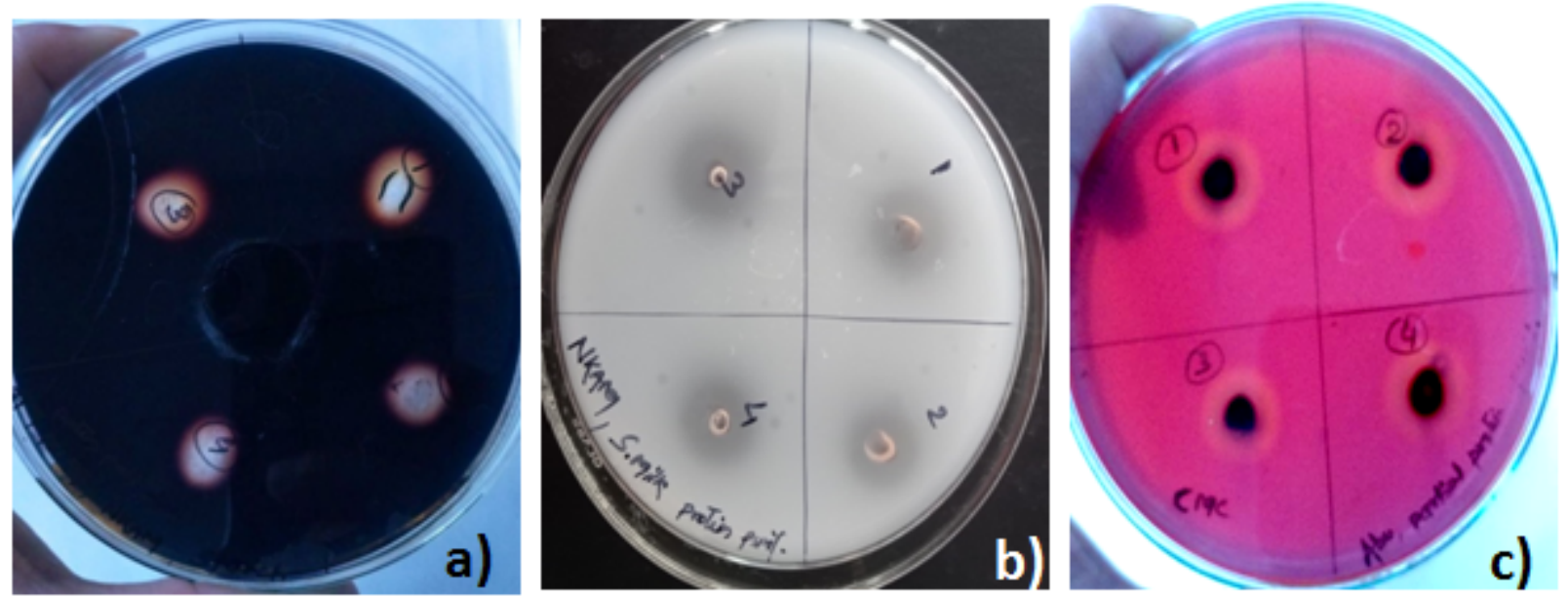

Figure 6

Bioactivity profiling of partially purified protein of \#7PSSTB. The cultural filtrate of most promising candidate \#7PSSTB was processed for partial purification of protein by salting out. The bioactivity profiling exhibited (a) Amylolytic activity (b) Protease activity (c) Cellulase activity with a zone size of 16 $\mathrm{mm}, 12 \mathrm{~mm}$ and $16 \mathrm{~mm}$ respectively

\section{Supplementary Files}

This is a list of supplementary files associated with this preprint. Click to download.

- Graphicalabstract.tif 